\title{
IMMUNOHISTOCHEMICAL DIFFERENTIATION OF TRIPLE NEGATIVE BREAST CANCER
}

\author{
Miroslav Lesar ${ }^{1}$, Mladen Stanec ${ }^{2}$, Nikola Lesar ${ }^{3}$, Danko Velimir Vrdoljak ${ }^{1}$, Zvonimir Zore ${ }^{1}$, Marija Ba- \\ nović ${ }^{4}$ and Gordana Brozović ${ }^{3,5}$ \\ ${ }^{1}$ Department of Oncology Surgery, ${ }^{2}$ Department of Oncology and Plastic Surgery, ${ }^{3}$ Department of Anesthesiology, \\ University Hospital for Tumors, Sestre milosrdnice University Hospital Center; ${ }^{4}$ student, School of Medicine, \\ University of Zagreb, Zagreb; ${ }^{5}$ Faculty of Medicine, University of Osijek, Osijek, Croatia
}

\begin{abstract}
SUMMARY - Based on immunohistochemical staining for the basal markers cytokeratin $5 / 6$ (CK 5/6), cytokeratin 14 (CK 14) and P-cadherin, triple negative tumors (TNT) are divided into two groups: 1) basal-like (BL) positive for one or all three markers; and 2) non basal-like (NBL) negative for all three markers. Even though the different origin of the cells of these two types of tumors implies different biological properties, they had been treated as one entity until recently. This paper analyzes TNT collected from 150 patients and distributed into two groups according to the results of immunohistochemical analysis, i.e. BL 116 (77.3\%) and NBL 34 (22.67\%). In this study, CK 5/6, CK 14 and P-cadherin were used as markers for identifying BL tumors. The immunohistochemical reaction was positive for CK 5/6 in 37\%, for CK 14 in 50.86\% and for P-cadherin in $68.34 \%$ of cases. The subclassification of triple negative breast cancer using the basal markers CK $5 / 6$, CK 14 and P-cadherin has enabled identification of BL and NBL breast cancers in a proportion that is in line with the only accurate analysis of TNT gene expression. Using the mentioned combination of markers in daily practice is easy to perform and economically affordable.
\end{abstract}

Key words: Carcinoma, ductal, breast; Triple negative breast neoplasms; Biomarkers, tumor; Basallike tumors; Non basal-like tumors; Adult

\section{Introduction}

The tumors whose cells do not express three groups of receptors, i.e. estrogen (ER), progesterone (PR) and human epidermal growth factor (HER2) receptors, pose a particular problem and huge enigma in breast cancer treatment. The tumors with these characteristics are called triple negative tumors (TNT) and they account for $15 \%-20 \%$ of all breast tumors. This diagnostic profile is in line with the aggressive behavior

Correspondence to: Miroslav Lesar, MD, PhD, Department of Oncology Surgery, University Hospital for Tumors, Sestre milosrdnice University Hospital Center, Ilica 197, HR-10000 Zagreb, Croatia

E-mail: duje.pag@gmail.com

Received October 5, 2015, accepted December 15, 2015 of the neoplasm, its increased risk of metastasis, and most importantly, very poor response to treatment ${ }^{1-4}$.

The triple negative group of breast tumors is not homogeneous. According to the latest findings of gene expression analysis and immunohistochemical differentiation methods, the triple negative tumors can be distributed into two subgroups, depending on the source of cancer cells. One subgroup consists of TNT originating from basal canal cells, the so called basal-like carcinoma. They account for $71 \%-91 \%$ of the triple negative breast cancers (TNBC). The second subgroup consists of about $9 \%-29 \%$ of TNT that do not originate from basal cells and are thus called non basal-like. Even though the different origin of the cells of these two types of tumors implies different biological properties, they had been treated as one entity until recently ${ }^{5-7}$. 
In clinical practice, the grouping of TNT can be done through immunohistochemical marking of the basal-like tumors using the so called basal markers. It is assumed that these tumors originate from the outer basal layer of the cells that show signs of both epithelia and smooth muscles and are therefore called myoepithelial (ME) cells. ME cells are defined as basal cells as they are located next to the basal membrane of the ductus and the acinus. They show high expression of basal cytokeratins (CK 5/6, CK 14, CK 8/18, CK 17), $\mathrm{P}$-cadherin, p63, vimentin, epidermal growth factor receptors (EGFR1) and c-kit ${ }^{8,9}$.

In order to increase the precision of immunohistochemical distribution of tumors into basal-like and non basal-like, it is necessary to use as many different markers as possible, such as CK 5/6, CK 14, CK 17, EGFR, P-cadherin, vimentin, fascin, nestin and moesin; they can be used individually or in combination. By using each of the 9 markers for TNT, the ratio of basal-like tumors would be up to $94 \%$ and this would include those tumors that are not in correlation with the results gained through a valid gene expression analysis.

Generally speaking, an increase in the number of markers increases test specificity and sensitivity ${ }^{10}$. However, as there is no such consensus on the criterion for identifying basal like tumors through immunohistochemical analysis, it is recommendable to use a limited number of markers, such as: CK 5/6, CK 14, CK 17, P-cadherin and EGFR ${ }^{5,11}$. In order to determine the best combination, the one that would be closest to the results of the gene expression analysis, in this study CK 5/6, CK 14 and P-cadherin were used as markers for identifying basal-like tumors.

\section{Materials and Methods}

The research was conducted on 150 samples of triple negative (TNT, no expression of estrogen, progesterone and HER2 receptors) invasive ductal breast carcinoma obtained during surgical procedures from patients in various stages of the disease. Patient age at the time of the procedure ranged from 32 to 82 . Each patient had a breast segment removed along with the accompanying tumor (segmentectomy) and the related axillary lymph node, or the entire breast with the tumor (ablation) along with the related axillary lymph node.
Two cuts of the paraffin block of each tumor tissue sample were used in receptor (estrogen and progesterone) demonstration. Two mouse monoclonal antibodies were used (estrogen, DAKO, Denmark, $\mathrm{N}^{0} \mathrm{H} 7098$, ready to use; and progesterone, DAKO, Denmark, $N^{0}$ M 3569, 1:50). Immunohistochemical staining was performed via automated use of the DAKO autostainer universal staining system machine and the Microwave Streptavidin ImmunoPeroxidase (MSIP) method, with the use of kit (DAKO; K 5007, according to the manufacturer's instructions), which contained the secondary HRP antibody, rabbit/mouse DAKO Real ${ }^{\mathrm{TM}}$ En Vision ${ }^{\mathrm{TM}}$. The results of the immunohistochemical analysis were shown semi-quantitatively by determining the percentage of positive cells (for a certain protein).

On semi-quantitative determination of the HER2 protein value, the HercepTest (K5204 package, DAKO, Denmark) containing all necessary reagents for proving the reaction was used. Primary mouse antibodies for human HER2 protein, secondary goat antibodies against rabbit immunoglobulin and visualization reagents - horseradish peroxidase bound to dextran polymer were used. The test has been approved by the United States Food and Drug Administration. By determining the expression of CK 5/6, CK 14 and $\mathrm{P}$-cadherin, the triple-negative invasive ductal breast carcinoma can be divided into so called basal-like and non basal-like carcinoma. Immunohistochemical determination of duct cells next to the basal membrane was conducted on the materials obtained by the tissue array method; tissue samples are obtained from paraffin blocks of the tumor from three different locations using a biopsy needle. Considering the heterogeneity of the tumor tissue, this allows for testing different proteins on the same tumor cells. The basal cells were demonstrated through the application of the mouse monoclonal antibodies to CK 5/6 (DAKO, Clone: D5/16 B4; ready to use), CK 14 (Novocastra, Product Code: NCL-LL002; Clone: LL002, 1:20) and Pcadherin (Novocastra, Product Code: NCL-P-Cad, Clone 56C1; 1:50).

The method was performed through the machine use of immunohistochemical staining test tubes (DAKO autostainer, universal staining system) according to the manufacturer's recommendations, through the use of the Microwave Streptavidin Im- 
muno Peroxidase (MSIP) method and the diaminobenzidine (DAB) visualization system, found in the kit along with the secondary antibody and necessary reagents (Envision/HRP, K 5007; DAKO). The results of the immunohistochemical analysis of CK $5 / 6$, CK 14 and P-cadherin were expressed using the following semi-quantitative method:

\begin{tabular}{lll}
\hline $0 \quad$ negative reaction & $\begin{array}{l}\text { no positivity in cell } \\
\text { cytoplasm }\end{array}$ \\
$+\quad$ weakly positive reaction & $<10 \%$ positive cells \\
++ & moderately strong & $10 \%-50 \%$ positive \\
$\quad$ positive reaction & cells \\
+++ strong positive reaction & $>50 \%$ positive cells \\
\hline
\end{tabular}

A positive reaction for one, two or three mentioned proteins implies a subtype of TNT invasive ductal breast carcinoma known as the basal-like tumor. The tumor samples that did not have any of the three stated markers (proteins) were defined as triple negative non basal-like tumors.

All analyses were performed with the use of IBM SPSS Statistics software, version 21 and OriginPro version 8.5. The receiver operating characteristic (ROC) curve was used to calculate specificity (true positive rate) and sensitivity (false positive rate). The area under the ROC curve (AUC) is a measure of how well a parameter can distinguish between two groups. The $\chi^{2}$-test was used to calculate the distribution of negative and positive values of CK 5/6, CK 14 and $\mathrm{P}$-cadherin.

\section{Results}

The triple negative tumors collected from $150 \mathrm{pa}^{-}$ tients were distributed into two groups based on im-

\section{Table 1. Expression of each marker in basal like tumor cells}

\begin{tabular}{|l|c|c|c|c|c|c|}
\hline Marker & \multicolumn{2}{|c|}{ Negative } & \multicolumn{2}{c|}{ Positive } & \multicolumn{2}{c|}{ Total } \\
\hline Cytokeratin 5/6 & 73 & $62.93 \%$ & 43 & $37.07 \%$ & 116 & $100 \%$ \\
\hline Cytokeratin 14 & 57 & $46.14 \%$ & 59 & $50.86 \%$ & 116 & $100 \%$ \\
\hline P-cadherin & 36 & $31.03 \%$ & 80 & $68.97 \%$ & 116 & $100 \%$ \\
\hline $\begin{array}{l}\text { Cytokeratin 5/6 } \\
\text { and/or 14 }\end{array}$ & 46 & $39.66 \%$ & 70 & $60.34 \%$ & 116 & $100 \%$ \\
\hline
\end{tabular}

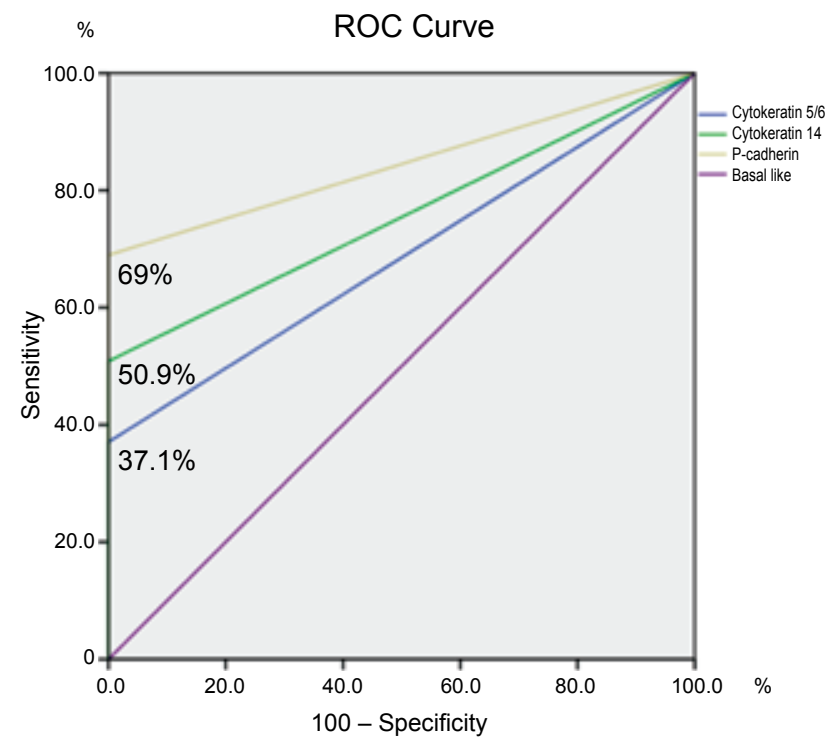

Fig. 1. Sensitivity of basal like tumor cells for each marker.

P-cadherin showed highest sensitivity for basal like tumors (69\%), followed by cytokeratin 14 (50.9\%) and cytokeratin 5/6 (37.1\%). The area under the curve (AUC) for P-cadherin was $84.5 \%$, for cytokeratin $75.4 \%$ and for cytokeratin $5 / 668.5 \%$, yielding a statistically significant difference at the level of $P=0.01$.

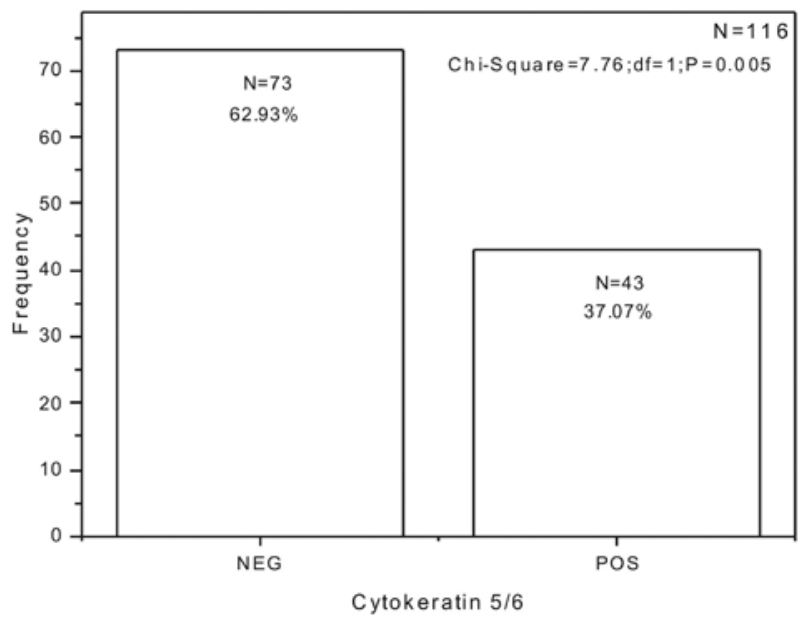

Fig. 2. Response of basal like tumors to cytokeratin 5/6 marker.

Distribution of negative and positive values of cytokeratin 5/6 showed a statistically significant difference $(P=0.005)$.

munohistochemical analysis: 1) basal-like (BL), 116 (77.33\%) samples positive for one or all three markers (CK 5/6, CK 14 and P-cadherin); and 2) non basal-like (NBL), $34(22.67 \%)$ samples negative for all three markers (CK 5/6, CK 14 and P-cadherin). 


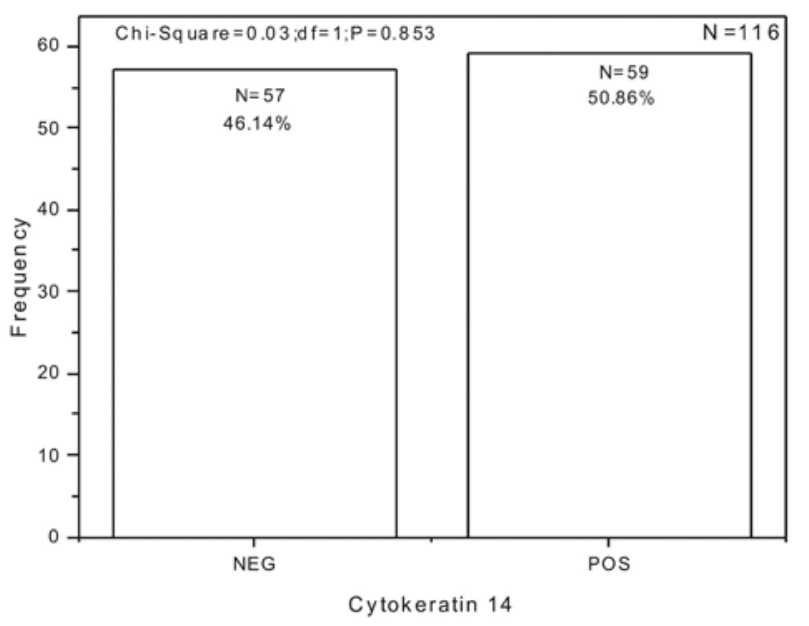

Fig. 3. Response of basal like tumors to cytokeratin 14 marker.

There was no statistically significant difference in the distribution of negative and positive values of cytokeratin 14 $(P=0.853)$.

The expression of each marker in basal-like tumor cells is illustrated in Table 1 and Figures 1-4. Cytokeratin 5/6 was found in the cells of 43 (37.07\%), CK 14 in 59 (50.86\%), and $\mathrm{P}$-cadherin in 80 (68.97\%) tumor samples (Table 1).

\section{Discussion}

During a single year, 1.35 million women in the world are diagnosed with invasive breast cancer and 450,000 women die. Despite significant advances in diagnosis and treatment methods for women with breast cancer, results are still far from being satisfactory. Every new piece of information that could contribute to understanding of cancer cell biology, which directly leads to better diagnosis and treatment, is very significant ${ }^{4}$.

Based on the expression of certain genes, 5 subclasses of breast tumors have been identified. The biggest difference in gene expression has been noted between HR positive and HR negative tumors.

Hormone receptor (HR) positive tumors are subdivided into two subgroups: luminal A (ER+, PR +, HER2-) and luminal B (ER+, PR+, HER2+). Both types express estrogen and progesterone genes but differ in their HER 2 protein expression. They account for $60 \%$ of malignant breast tumors and have good

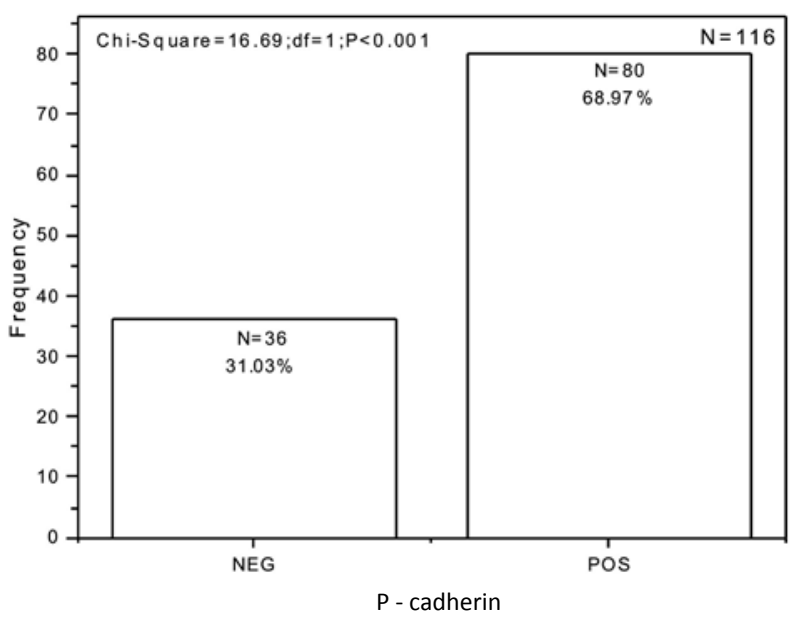

Fig. 4. Response of basal like tumors to P-cadherin marker.

Distribution of negative and positive values of $\mathrm{P}$-cadherin showed a statistically significant difference $(P<0.001)$.

prognosis. HR negative tumors are divided into three distinct subgroups: HER2 (ER-, PR-, HER2+), normal-like (ER \pm , PR \pm , HER2-), and basal-like (ER-, PR-, HER2-; triple negative tumors). They account for $40 \%$ of all cases of breast cancer ${ }^{12}$. They have various prognoses and treatment options. In this sense, the worst prognosis and treatment options come with TNT, which do not express estrogen, progesterone and HER2 receptors. Furthermore, based on the analysis of gene activity, it has been confirmed that TNT are not homogeneous. The basal-like tumors make up the biggest part of the group of TNT $(70 \%$ 90\%), while the rest are non basal-like. The basal-like subtype represents a homogeneous group of tumors sharing a common genetic profile, treatment response and prediction of the course of illness ${ }^{5,11,13,14}$.

So far, there has not been enough information about difference in the malignant potential of TNT considering the origin of cancer cells, and the question being posed is whether differences in the prognosis and treatment among a small share of patients with triple negative cancer are a result of the malignant potential within the TNT considering their basal-like and non basal-like origin.

This paper analyzes TNT collected from $150 \mathrm{pa}-$ tients distributed into two groups according to the results of immunohistochemical analysis, i.e. basal-like (77.3\%) and non basal-like (22.67\%). However, 
the immunohistochemical distribution of tumors using basal markers can be fairly unreliable. So, data from other research show a significant variation in the presence of basal-like tumors among the analyzed triple negative breast cancers, ranging from $42 \%$ to $88 \% \%^{9,15-17}$. However, our data on the distribution of each tumor subtype are in accordance with the data available, even those in which the classification was based on the expression of 500 different genes and where the presence of basal-like tumor was $71 \%$.

In order to increase the accuracy of the immunohistochemical distribution of tumors into basal-like and non basal-like, it is necessary to use as many different markers as possible, such as CK 5/6, CK 14, CK 17, EGFR, P-cadherin, vimentin, fascin, nestin and moesin; they can be used individually or combined. Using each of the 9 markers for TNT would increase the share of basal-like tumors to up to $94 \%$ and this would include those that are not in correlation with the results obtained by the only valid gene expression analysis. Generally speaking, increasing the number of markers increases the test specificity and sensitivity $^{10}$. However, as there is no general consensus on the criteria for identifying basal-like tumors through immunohistochemical analysis, it is recommendable to use a limited number of markers, such as CK 5/6, CK 14, CK 17, P-cadherin and EGFR ${ }^{5,11}$. The immunohistochemical reaction was positive for CK 5/6 in $37 \%$, for CK14 in $50.86 \%$ and for P-cadherin in $68.34 \%$ of cases. The literature data available on the same markers show the following results: positive reaction for CK 5/6 and CK 14 in 42\%-88\% and for $\mathrm{P}$-cadherin in $93 \%$ of cases $^{15}$.

Using the aforementioned combination (CK 5/6, CK 14 and P-cadherin) for identifying basal-like tumors, we managed to identify the percentage of these tumors, which is closest to the results of the immunohistochemical analysis (65\%-90\%) and gene expression analysis $(71 \%)^{5,14,17}$. The achieved result of $77.7 \%$ basal-like tumors indicates a good combination of basal markers used.

The subclassification of triple negative breast cancers using the basal markers CK 5/6, CK 14 and Pcadherin enabled identification of basal-like and non basal-like breast cancers in a proportion that is in line with the only accurate analysis of TNT gene expression. Using the mentioned combination of markers in everyday practice is easy to perform and economically affordable.

\section{Acknowledgments}

We acknowledge the expert technical assistance of Miroslav Banović, MD, PhD, in the method development, and the participants for their time and efforts.

\section{References}

1. De Ruijter TC, Veeck J, Hoon JP, van Engeland M, TjanHeijnen VC. Characteristic of triple negative breast cancer. J Cancer Res Clin Oncol. 2011;137:183-92, doi: 10.07/s00432010-0957-x.

2. Li J, Chen Z, Su K, ZengJ. Clinicopathological classification and traditional prognostic indicators of breast cancer. Int J Clin Exp Pathol. 2015;8:8500-5.

3. Chen HL, Ding A, Wang FW. Prognostic effect analysis of molecular subtype on young breast cancer patients. Chin J Cancer Res. 2015;27:428-36, doi: 10.3978/j.issn.1000-9604 2015.08.02.

4. Zhang C, Wang S, Israel HP, Yan SX, Horowitz DP, Crockford $\mathrm{S}$, et al. Higher locoregional recurrence rate for triplenegative breast cancer following neoadjuvant chemotherapy, surgery and radiotherapy. Springerplus. 2015;30:4:386.

5. Rakha EA, Elsheikh SE, Aleskandarany MA, Habashi HO, Green AR, Powe DG, et al. Triple-negative breast cancer: distinguishing between basal and non basal subtypes. Clin Cancer Res. 2009;15:2302-10, doi: 10.1158/1078-0432,CCR-08-2132.

6. Thike AA, Cheok PY, Jara-Lazaro AR, Tan B, Tan P, Tan PH. Triple negative breast cancer: clinicopathological characteristics and relationship with basal like breast cancer. Mod Pathol. 2010;23:123-33.

7. Wahba HA, E1-Hadaad HA. Current approaches in treatment of triple-negative breast cancer. Cancer Biol Med. 2015;12:106-16, doi: 10.7497/j.issn.20095-3941.2015.0030.

8. Nielsen TO Hsu FD, Jensen K, Cheang M, Karaca G, Hu Z. Immunohistochemical and clinical characterization of the basal like subtype of invasive breast carcinoma. Clin Cancer Res. 2004;10:5367-74.

9. Bertucci F, Finetti P, Cervera N, Esterni B, Hermite F, Viens $\mathrm{P}$, et al. How basal are triple negative breast cancer? Int J Cancer. 2008;123:236-40, doi: 10.1002/ijc. 23518.

10. Thike AA, Igbal J, Cheok PY. Triple negative breast cancer: outcome correlation with immunohistochemical detection of basal markers. Am J Surg Pathol. 2010;34:56-64, doi: 10.1097/PAS.ObO13e3181eO2f45.

11. Kumar N, Patni P, Agarwal A, Khan MA, Parashar N. Prevalence of molecular subtypes of invasive breast cancer: a retrospective study. Med J Armed Forces India. 2015;7:254-8, doi: 10.1016/j.mjafi.2015.04.006. 
12. Sorlie T, Perou CM, Tibshirani R, Aas T, Geisler S, Johnsen $\mathrm{H}$, et al. Gene expression patterns of breast carcinomas distinguish tumor subclasses with clinical implications. Proc Natl Acad Sci USA. 2001;98:10869-74, doi: 10.1073/ pnas.191367098.

13. Sotiriou C, Phil D, Pusztaj J. Gene expression signatures in breast cancer. N Engl J Med. 2009;360:790-800, doi: 10.1056/NEJMra0801289.

14. Jamdade VS, Sethi N, Mundhe NA, Kumar P, Lahkar M, Sinha N. Therapeutic targets of triple-negative breast cancer: a review. Br J Pharmacol. 2015;172:4228-37,doi:10.1111/ $\mathrm{bph} / 13211$.
15. Carey L, Winer E, Viale G, Cameron D, Gianni L. Triple negative breast cancer: disease entity or title of convenience? Nat Rev Oncol. 2010;7:683-92, doi:10.1038/nrclinoc.2010. 154.

16. Choo JR, Nielsen TO. Biomarkers for basal like breast cancer. Cancers. 2010;2:1040-65, doi: 10.3390/cancers2021040.

17. RakhaI,ElliasI. Triplenegative basallikebreastcancer: review. Pathology. 2009;41:40-7, doi: 10.1080/00313020802563510.

Sažetak

\title{
IMUNOHISTOKEMIJSKA DIFERENCIJACIJA TROSTRUKO NEGATIVNOG RAKA DOJKE
}

\author{
M. Lesar, M. Stanec, N. Lesar, D. V. Vrdoljak, Z. Zore, M. Banović i G. Brozović
}

$\mathrm{Na}$ osnovi imunohistokemijske analize bazalnih biljega citokeratin 5/6 (CK 5/6), citokeratin 14 (CK 14) i P-kadherin trostruko negativni tumori (TNT) su podijeljeni u dvije skupine: 1. basal-like (BL) (pozitivni na jedan ili sva tri biljega) i 2. non basal-like (NBL) (negativni na sva tri biljega). Iako različito podrijetlo stanica ovih dvaju tipova tumora upućuje i na njihova različita biološka svojstva, sve donedavno tretirani su kao jedan entitet. U našem su radu za identifikaciju basal-like tumora korišteni biljezi CK 5/6, CK 14 i P-kadherin. Imunohistokemijska reakacija na CK 5/6 bila je pozitivna u 37\%, na CK 14 u 50,86\% i na P-kadherin u 68,34\% uzoraka. U ovom su radu TNT prikupljeni od ukupno 150 bolesnica razvrstani temeljem imunohistokemijske analize u dvije skupine: basal-like 116 (77,33\%) i non basal-like 34 (22,67\%). Subklasifikacija TNT dojke uz pomoć bazalnih biljega CK 5/6, CK 14 i P-kadherina omogućila je identifikaciju basal-like i non basal-like tumora dojke u omjeru koji je u skladu s jedino točnom analizom genske ekspresije TNT. Primjena navedene kombinacije biljega u svakodnevnoj je praksi lako izvediva i ekonomski nezahtjevna.

Ključne riječi: Karcinom dojke, duktalni; Trostruko negativni tumori dojke; Biomarkeri, tumorski; Bazalni tumori; Nebazalni tumori; Odrasla osoba 